\title{
Calcium carbonate precipitation by urease and carbonic anhydrase positive bacteria
}

\author{
Üreaz ve karbonik anhidraz pozitif bakteriler tarafindan kalsiyum \\ karbonat çökelimi
}

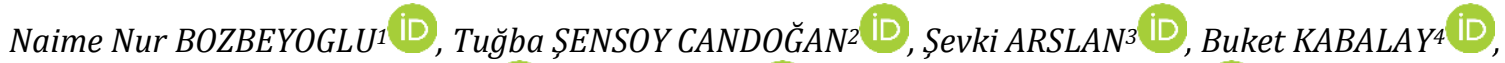 \\ Omer BOZKAYA ${ }^{5}$ (D) Erdal AKYOL ${ }^{6}$ (D) Nazime MERCAN DOĞAN ${ }^{*}$ (D)
}

\begin{abstract}
1,2,3,4,7Department of Biology, Faculty of Arts and Science, Pamukkale University, Denizli, Turkey. nbozbeyoglu@pau.edu.tr, sensoytugba@gmail.com, sevkia@pau.edu.tr,kabalaybuket@gmail.com,nmercan@pau.edu.tr 5,6Department of Geology, Faculty of Engineering, Pamukkale University, Denizli, Turkey. obozkaya@pau.edu.tr, eakyol@pau.edu.tr
\end{abstract}

\section{Abstract}

In present study, $\mathrm{CaCO}_{3}$ precipitation was examined in two ureolytic bacteria. Bacillus aerius U2 and Sporosarcina pasteurii ATCC 6453 were used as test organisms. The determination of urease and carbonic anhydrase enzyme activities were also determined. For further confirmation of the calcium carbonate mineral type produced by bacteria, XRD, SEM and EDX analysis were done. Strain U2 produced calcite and vaterite. In S. pasteurii ATCC 6453, only vaterite was found. The enzyme activity studies showed that both urease and carbonic anhydrase activities was 2-50-fold higher in S. pasteurii ATCC 6453 than B. aerius U2. Although, S. pasteurii ATCC 6453 was better option for microbial calcium carbonate precipitation (MCP) at higher temperature, by B. aerius $U 2$ at lower temperature $\left(<30^{\circ} \mathrm{C}\right)$ is made possible to employ in the most geotechnical applications.

Keywords: Precipitation, Calcium carbonate, Carbonic anhydrase, Urease, Ureolytic bacteria.

\section{Introduction}

$\mathrm{CaCO}_{3}$ precipitation by ureolytic bacteria is one of the important scientific issues due to its importance in engineering. Previous studies in the scientific community have reported that many environmental problems could be solved with ureolytic bacteria [1]-[3]. The formation of microbial calcium carbonate starts with urea hydrolysis catalyzed by the urease enzyme. When ureolytic bacteria are found in calcium-rich media, the reaction between calcium and carbonate ions occurs due to the high $\mathrm{pH}$ caused by urea hydrolysis. As a result of this reaction, calcium carbonate crystals tprecipitate in the environment. The biological, chemical, and physical factors such as $\mathrm{pH}$ temperature, urease enzyme activity and calcium ions can affect the bacterial precipitation [4]-[8]. Also, the bacterium type is an important because the type of mineral, size and biochemical structure of calcium carbonate varies as according to the species of bacteria. In order to determine the effect of bacterial strains, numerous researchers have intensified on this subject [9]-[16]. In this study, we aimed to compare and analyze two bacterial calcium carbonate precipitation by Bacillus aerius $\mathrm{U} 2$ and Sporosarcina pasteurii ATCC 6453. Moreover, the role of
Öz

Bu çalışmada, iki üreolitik bakteride $\mathrm{CaCO}_{3}$ çökelimi araştırılmıştır. Test organizması olarak Bacillus aerius U2 ve Sporosarcina pasteurii ATCC 6453 türleri kullanılmıstır. Bunların yanında, bakterilerin üreaz ve karbonik anhidraz enzim aktiviteleri de tespit edilmistir. Bakteriler tarafindan üretilen kalsiyum karbonatın mineral tipi konformasyonu için XRD, SEM ve EDX analizleri gerçekleștirilmiștir. B. aerius U2 suşu kalsit ve vaterit üretmiștir. S. pasteurii ATCC 6453 susunda sadece vaterit bulunmuştur. Enzim aktivitesi çalıșmalarının sonuçlarına göre S. pasteurii ATCC 6453, B. aerius U2'den 2-50 kat daha fazla aktivite göstermiștir. Yüksek sıcakllklarda kalsiyum karbonat çökelimi için $S$. pasteurii ATCC 6453 türü tercih edilebilirken, daha geniş iklim bölgelerini kapsayan düsük sıcaklıklarda $\left(<30^{\circ} \mathrm{C}\right) \mathrm{B}$. aerius U2 türünün kullanım potansiyeli bulunmaktadır.

Anahtar kelimeler: Çökelim, Kalsiyum karbonat, Karbonik anhidraz, Üreaz, Üreolitik bakteriler.

\footnotetext{
${ }^{*}$ Corresponding author/Yazışılan Yazar
}

urease and carbonic anhydrase enzymes in this process was determined for the first time. The structures of bacterial calcium carbonate were analyzed by XRD, SEM, DTA and TGA throughout in this study.

\section{Material and methods}

\section{$2.1 \quad$ Materials}

Bacillus aerius U2 and Sporosarcina pasteurii ATCC 6453 were used as organisms. B. aerius $\mathrm{U} 2$ was isolated in our previous study [17]. The bacteria were obtained from Pamukkale University, Department of Biology, Bacteriology Laboratory Denizli, Turkey.

\subsection{Calcium carbonate precipitation}

For screening precipitation, Calcium Precipitation Medium (CPM), containing $3.0 \mathrm{~g} / \mathrm{L}$ Nutrient Broth (Difco), $25 \mathrm{mM} \mathrm{CaCl}_{2}$, $25 \mathrm{mM} \mathrm{NaHCO}_{3}$ and $333 \mathrm{mM}$ urea, was used. The experimental parameters for mineralization were given in Table 1 . The amount of precipitated $\mathrm{CaCO}_{3}$ was measured by EDTA titrimetric method [18] and calculated by the formula of 
$\left[\mathrm{CaCO}_{3}=(\mathrm{V} 1 . \mathrm{M} .1000) / \mathrm{V} 2\right), \mathrm{V} 1$ : consumed EDTA, M: $1 \mathrm{~mL}$

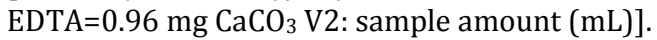

Table 1 . The experimental parameters of calcium carbonate precipitation.

\begin{tabular}{ccc}
\hline & B. aerius & S. pasteurii \\
\hline $\mathrm{pH}_{\text {initial }}$ & 5.5 & 6.5 \\
$\mathrm{pH}_{\text {final }}$ & 8.64 & 8.20 \\
Nutrient broth $(\mathrm{g} / \mathrm{L})$ & 3 & 3 \\
$\mathrm{NaHCO}_{3}(\mathrm{mM})$ & 25 & 25 \\
Urea $(\mathrm{mM})$ & 333 & 333 \\
Temperature $\left.^{\circ} \mathrm{C}\right)$ & 20 & 30 \\
$\mathrm{CaCl}_{2}(\mathrm{mM})$ & 25 & 25 \\
Inoculation rate $(\%)$ & 10 & 10 \\
Days & 14 & 7 \\
Amount of CaCO $(\mathrm{mg} / \mathrm{mL})$ & 1319.84 & 2594.50 \\
\hline
\end{tabular}

\subsection{Urease enzyme activity}

Urease enzyme activity was measured by phenol-hypochlorite method slightly modified in our lab [19]. Briefly, ureolytic bacteria were incubated in calcium precipitation media (CPM) and Luria Bertani-Miller (LB) supplemented with urea. Then, the enzyme crude extract from $B$. aerius $\mathrm{U} 2$ strain and $S$. pasteurii ATCC 6453 were obtained by ultrasonicator. The bacterial enzyme crude extract was added to reaction mixture (phosphate buffer, $0.1 \mathrm{M}, \mathrm{pH} 7.4$ and $50 \mathrm{mM}$ urea) and all incubated at $37^{\circ} \mathrm{C}$ for $30 \mathrm{~min}$. At the end of the incubation, 50 $\mu \mathrm{l}$ reaction mixture was added to $500 \mu \mathrm{l}$ of phenolnitroprusside solution. For color formation, $500 \mu \mathrm{l}$ of alkali hypochlorite solution was added and incubated at $37{ }^{\circ} \mathrm{C}$ for $20 \mathrm{~min}$. This mixture measured by spectrophotometry at $630 \mathrm{~nm}$. Enzyme activity was determined by standard curve generated with $\left(\mathrm{NH}_{4}\right)_{2} \mathrm{SO}_{4}$. One unit of urease activity is the amount of enzyme needed to hydrolyze $1 \mu \mathrm{mol}$ of urea per min at $37^{\circ} \mathrm{C}$.

\subsection{Carbonic anhydrase enzyme activity}

Carbonic anhydrase activity was determined according to method by Armstrong et al. [20]. Some optimization and modifications was done in our lab. Briefly, $100 \mu \mathrm{l}$ of the crude enzyme prepared by ultrasonicator was added to $900 \mu \mathrm{l}$ of the mixture consisting of phosphate buffer (100 mM, pH 7.2) and $p$-nitrophenyl acetate $(3 \mathrm{mM})$. Absorbance was measured at $412 \mathrm{~nm}$ at least $5 \mathrm{~min}$. Enzyme activity was determined by standard curve prepared with $p$-nitrophenol. One unit of enzyme activity was expressed as $1 \mu \mathrm{mol}$ of pnitrophenyl acetate hydrolysed per minute.

\subsection{Minerological analysis (XRD, SEM and TGA)}

The XRD analysis of precipitated $\mathrm{CaCO}_{3}$ from bacteria was done at İstanbul University. TGA analysis was performed in a Perkin Elmer SII-Diamond. The samples were heated from 0 to $1000{ }^{\circ} \mathrm{C}$ at a heating rate of $10^{\circ} \mathrm{C} / \mathrm{min}$. For SEM analysis, the samples were coated with gold and palladium and analyzed by FESEM. The analyses of TGA and SEM were done at Pamukkale University, Denizli, Turkey.

\subsection{Statistical analyses}

The Minitab statistical software package was used for statistical analyses. Each data was given as means including their Standard Error of Means (SEM). Student $t$-test was used to compare the date sets and $\mathrm{p}<0.05$ was chosen for level of statistical significance.

\section{Results and discussion}

\subsection{Calcium carbonate precipitation}

Screening the organisms and parameters of growth for the precipitation of $\mathrm{CaCO}_{3}$ is laborious and time consuming. However, it is not suspected that bacterial precipitation is both variable according to both bacteria types and growth parameters. In this study, B. aerius U2 and S. pasteurii ATCC 6453 of their precipitation abilities were compared. Parameters of urea concentration, different initial $\mathrm{pH}$, temperature, inoculation rate and incubation times were tested in our study (data not shown) and the best conditions of both bacteria for precipitation were presented in Table 1. Although both bacteria were capable of precipitating calcium carbonate, the amount of precipitated calcium carbonate was different. For example, the results indicate that highest $\mathrm{CaCO}_{3}$ mineralization for B. aerius $\mathrm{U} 2$ was calculated as $1319.84 \mathrm{mg} / \mathrm{ml}$ in 14 days. On the other hand, this value was found as $2594.50 \mathrm{mg} / \mathrm{ml}$ in 7 days for ATCC 6453 strain. In contrast to B. aerius U2, S. pasteurii ATCC 6453 accumulated more carbonate in less time. When compared B. aerius U2 and S. pasteurii ATCC 6453, lower calcium carbonate precipitation was observed in $B$. aerius $\mathrm{U} 2$. Our urease activity results were parallel to that precipitation result also. But, this strain could precipitate calcium carbonate properly. It was well established that, urease activity in bacteria varies from strain to strain. For example, urease activities of $B$. megaterium were different from $S$. pasteurii [21]. Also these results were parallel to our results. On the other hand, there are no correlation between urease activity and bio-calcification [22]. Besides these, Bacillus aerius U2 achieved maximum calcium carbonate precipitate at the end of a longer incubation (14 days) compared to S. pasteurii ATCC 6453 (7 days). $S$. pasteurii ATCC 6453 precipitated more calcium carbonate than $B$. aerius $\mathrm{U} 2$ in a shorter time. This was due to higher urease activity. Undoubtedly, the incubation time was a significant advantage. But, the ability of precipitation of $\mathrm{U} 2$ at lower temperature was also an advantage of this bacterium. It is well established that, one of the important factor affecting the growth and activity of bacteria is temperature. Studies on bacterial calcium carbonate precipitation in the literature have shown that low temperature is not effective in this process [23],[24]. It was determined that B. aerius U2 effectively precipitated calcium carbonate at low temperature $\left(20^{\circ} \mathrm{C}\right)$. Perhaps, B. aerius U2 can be used to improve problematic soils by changing mechanical properties of these soils such as uniaxial compressive strength, young's modulus etc. [17].

The $\mathrm{pH}$ values of the growth media are very important in biomineralization as well as in microbial activity. In addition, studies conducted by many researchers have shown that bacterial calcium carbonate precipitation activity was higher at alkaline pH. [25]-[27]. The initial $\mathrm{pH}$ of precipitation in B. aerius U2 was 5.5, while $S$. pasteurii ATCC 6453 was 6.5. The final pH values were very closed in both bacteria (8.64 for B. aerius U2 and 8.2 for $S$. pasteurii ATCC 6453). In other words, the best precipitation was almost the same alkali conditions. It is well known that urease activity was higher in neutral or alkaline $\mathrm{pH}$. Higher microbial precipitation in alkaline $\mathrm{pH}$ was most probably due to higher urease activity in that $\mathrm{pH}$ for both bacterial strain. 


\subsection{X-ray diffraction}

According to the results obtained from XRD analysis, amorphous (EPS) phase, calcite and vaterite as calcium carbonate crystals were observed in $\mathrm{CaCO}_{3}$ produced by B. aerius U2. In addition, as the increasing incubation time for $B$. aerius $\mathrm{U} 2$ increased the ratio of calcite/vaterite and crystal/amorphous (Figure 1). For ATCC 6453 strain, only vaterite was observed in the XRD analysis of $\mathrm{CaCO}_{3}$ precipitation medium containing $1000 \mathrm{mM} \mathrm{CaCl} 2$ (14 $4^{\text {th }}$ days) (Figure 2). In other words, calcite was not seen under this condition. There were different forms of microbial $\mathrm{CaCO}_{3}$ such as calcite, vaterite, aragonite etc. Different bacteria or strains can form different mineral types in different growth conditions [17],[28]-[31]. For example, Synechococcus leopoliensis PCC 7942 can form aragonite-like $\mathrm{CaCO}_{3}$ [31]. B. megaterium, B. cereus, B. subtilis and B. thuringiensis can form calcite and vaterite, while $L$. fusiformis produce pure vaterite [32]. This is due to growth conditions and calcium carbonate precipitation parameters.

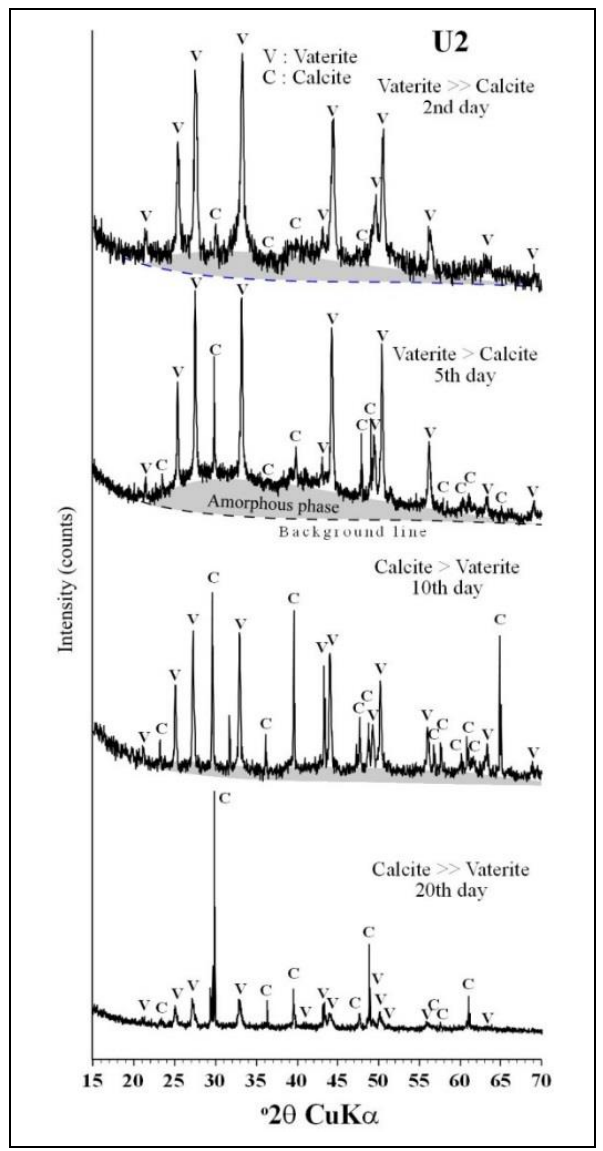

Figure 1. XRD data of precipitated $\mathrm{CaCO}_{3}$ in B. aerius.

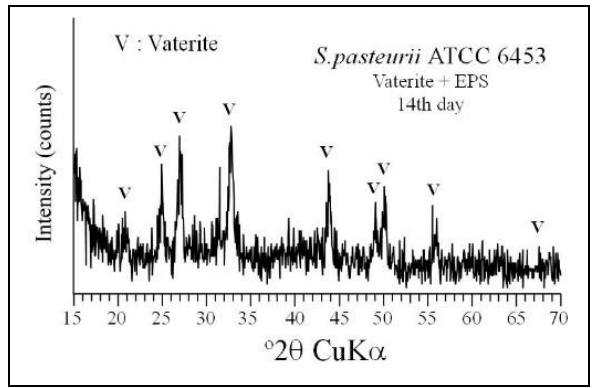

Figure 2. XRD data of precipitated $\mathrm{CaCO}_{3}$ in $\mathrm{S}$. pasteurii.

\subsection{SEM analyses}

Figure 3 and 4 present SEM photomicrographs of precipitated $\mathrm{CaCO}_{3}$ in strains $B$. aerius $\mathrm{U} 2$ and $S$. pasteurii ATCC 6453. Amorphous phase (EPS) and the mineral type of the calcium carbonate in B. aerius U2 strain and S. pasteurii ATCC 6453 strain were confirmed by SEM analysis. EPS as polymeric formations in amorphous structure, spherical vaterite and trigonal structure was shown in photomicrographs (Figure 3). In addition, the SEM-EDX analysis performed on the S. pasteurii ATCC 6453 calcium carbonate precipitate determined the mass percentage of the elements contained in the sample (Figure 4). The presence of vaterite and calcite observed in XRD and DTA-TGA analyses in bacterial calcium carbonate precipitates was supported by the results of SEM-EDX analysis.

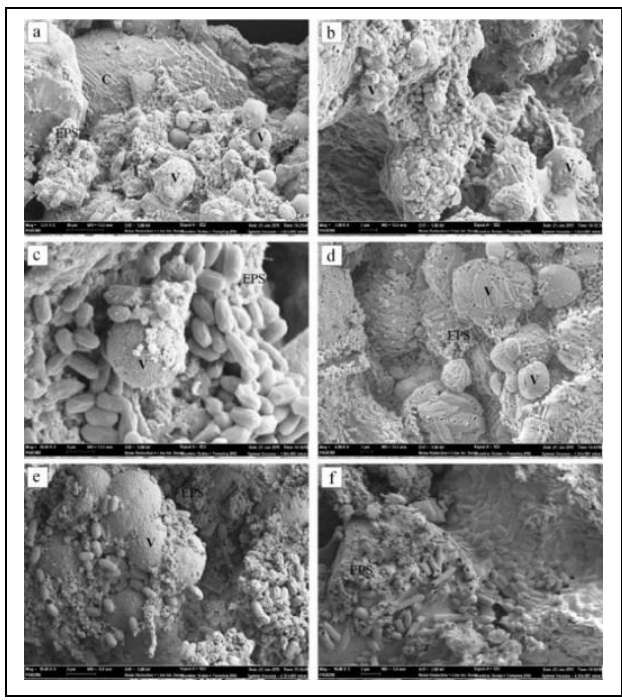

Figure 3. The SEM images of precipitated $\mathrm{CaCO}_{3}$ in B. aerius. (a): Calcite (c): vaterite (V) and amorphous formations (EPS), (b-e): Cells formed bacillus $(1 \mu \mathrm{m})$ vaterite and polymeric formations, (f): Cell colonies.

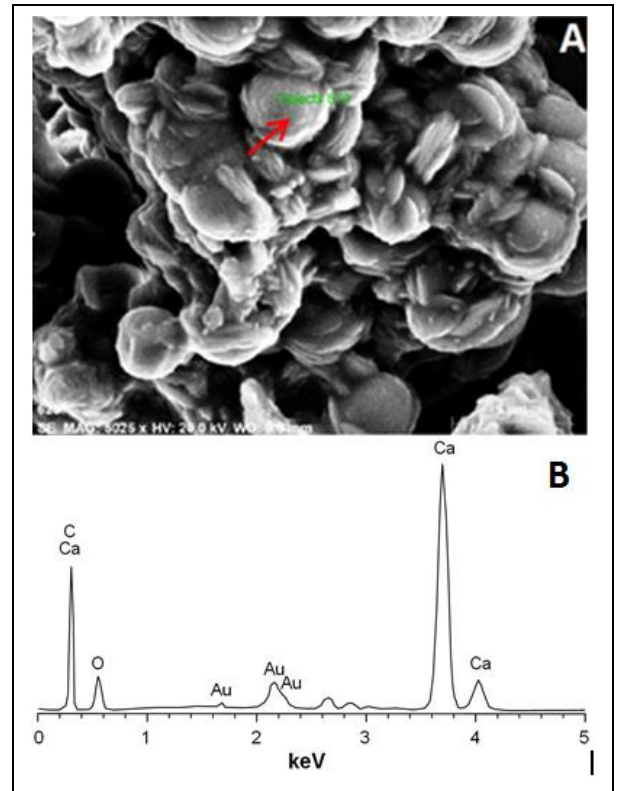

Figure 4. SEM-EDX analysis of precipitated calcium carbonate in S. pasteurii. (A): Vaterite formations. (B): Mass \% of elements. 


\subsection{Thermal analyses}

Two phases were observed by B. aerius $\mathrm{U} 2$ as endothermic and exothermic in the thermal analysis of calcium carbonate sediments (Figure 5). The exothermic peak corresponds to an energy release associated with the decomposition of the amorphous (EPS) phase, which corresponds to a $10 \%$ weight loss. Calcite and vaterite destruction was observed in thermal analysis as seen exothermic peak close to $700{ }^{\circ} \mathrm{C}$. This caused approximately $40 \%$ weight loss. Moreover, this was increased up to $63 \%$ at the end of the 48 hour incubation (51-63\%). This confirms the XRD analysis results by demonstrating the high amount of EPS as amorphous phase in the bacterial calcium carbonate precipitate (Figure 2).

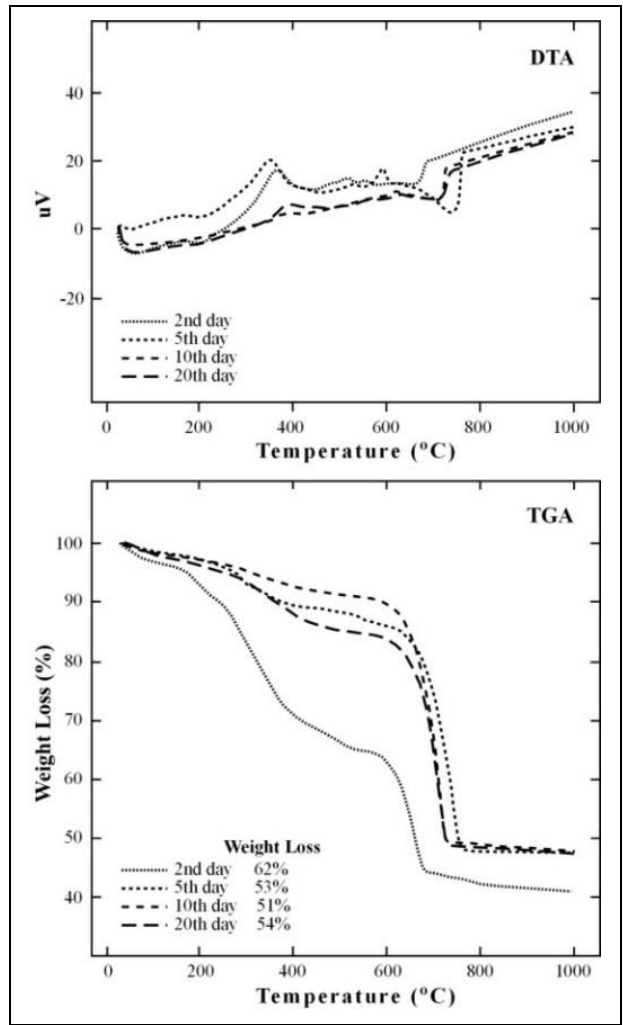

Figure 5. DTA and TGA analysis of precipitated calcium carbonate in Bacillus aerius.

\subsection{Enzymes activities}

It is well established that Urease and Carbonic anhydrase enzymes are involved in bacterial calcium carbonate precipitation. These two enzymes have different role in this process. Urease involved in calcium carbonate mineralization by hydrolyzing urea into ammonium and carbonate in the alkaline environment. On the other hand, the carbonic anhydrase catalyzes reversible hydration of $\mathrm{CO}_{2}$. Urease and carbonic anhydrase activities were determined for the first time in two different medium (LB-UREA and CPM) in both bacteria. Urease enzyme activity of $\mathrm{U} 2$ was calculated as $1.52 \pm 0.1 \mu \mathrm{mol} / \mathrm{min} / \mathrm{mg}$ protein in LB-urea medium and $0.44 \pm 0.02 \mu \mathrm{mol} / \mathrm{min} / \mathrm{mg}$ protein in CPM. Urease enzyme activity was induced approximately 3 -fold in LB-urea medium compared to CPM. S. pasteurii ATCC 6453 urease enzyme activities were found $5.36 \pm 0.1$ and $24.98 \pm 5.0 \mu \mathrm{mol} / \mathrm{min} / \mathrm{mg}$ protein for LB-urea and CPM, respectively. In contrast to strain U2 urease, strain ATCC 6453 urease activity was higher in CPM (Table 2). Similar to our results many bacterial strains including Bacillus and Pseudomonas with high enzyme activities showed high $\mathrm{CaCO}_{3}$ precipitation [33]. Omoregie et al. [22] reported that urease activities for the bacteria isolated from limestone caves had higher urease activity. In addition, Sun et al. [21] emphasized that the urease activity of B. megaterium was lower than that of $S$. pasteurii at high temperatures such as $25{ }^{\circ} \mathrm{C}$ and $30^{\circ} \mathrm{C}$. It is well established that urease enzyme activity was regulated by environmental conditions such as nitrogen content. The nitrogen amount of CPM and LB-urea were different. Therefore, enzyme activity was different in two medium. Moreover, type, physiological requirement, and nitrogen demands are different for two bacteria. Therefore, urease enzyme activities may regulate different manner in two bacteria. Although strain U2 showed low urease activity in CPM, CPM also made calcite mineralization [34]. However, future works are needed to solve underlying mechanisms of urease induction in different medium.

In addition to urease, carbonic anhydrase activity was also determined in this study. Carbonic anhydrase enzyme activity is highly effective in calcium carbonate precipitation. This enzyme activity for $B$. aerius U2 was found $30.75 \pm 1.76$ and $42.30 \pm 5.4 \mathrm{nmol} / \mathrm{min} / \mathrm{mg}$ protein in LB urea and CPM, respectively. 1.38-fold induction was found in two different medium but this change was not found statistically significant. Similarly 1.82 fold difference was found in between CPM and LB-urea medium for ATCC $6453(61.9 \pm 5.7 \mathrm{nmol} / \mathrm{min} / \mathrm{mg}$ protein for LB urea and $112.9 \pm 9.4 \mathrm{nmol} / \mathrm{min} / \mathrm{mg}$ protein for CPM). These results showed that S. pasteurii ATCC 6453 had higher urease and carbonic anhydrase activity than B. aerius $\mathrm{U} 2$ (Table 2).

Table 2. Urease and carbonic anhydrase enzyme activity.

\begin{tabular}{cccc}
\hline medium & Bacteria & $\begin{array}{c}\text { Urease activity } \\
(\mu \mathrm{mol} / \mathrm{min} / \mathrm{mg})\end{array}$ & $\begin{array}{c}\text { Carbonic anhydrase } \\
\text { activity } \\
(\mathrm{nmol} / \mathrm{min} / \mathrm{mg})\end{array}$ \\
\hline LB-Urea & B. aerius & $1.52 \pm 0.1$ & $30.75 \pm 1.76$ \\
& S. pasteurii & $5.36 \pm 0.1^{*}$ & $61.9 \pm 5.7^{*}$ \\
CPM & B. aerius & $0.44 \pm 0.02$ & $42.30 \pm 5.4^{*}$ \\
& S. pasteurii & $24.98 \pm 5.0^{*}$ & $112.9 \pm 9.4^{*}$ \\
\hline
\end{tabular}

*: Significantly different from the respective $B$. aerius $\mathrm{U} 2$ value $(\mathrm{p}<0.05)$.

\section{Conclusions}

In this study, it was examined $\mathrm{CaCO}_{3}$ precipitation in two ureolytic bacteria and verified mineral types with XRD and SEM for the first time. S. pasteurii ATCC 6453 synthesized vaterite crystals. The calcium carbonate precipitates consisted of calcite and vaterite crystals in B. aerius U2. Also, strain U2 precipitated calcium carbonate at $20{ }^{\circ} \mathrm{C}$. Bacterial calcium carbonate mineralization is a highly complex metabolic activity of cells. If we want to solve an environmental problem, we must investigate and optimize each organism under its own conditions of urea hydrolysis and bio-mineralization. We thought that $B$. aerius $\mathrm{U} 2$ could be used as a potential bacterium in a wide range of climatic zones, mainly in geotechnical applications. And finally, this study was the first document on the urease and carbonic anhydrase activities of both bacteria in LB-UREA and CPM.

\section{Acknowledgments}

This study was supported by the Scientific Research Council of Pamukkale University (research grant 2013FBE017 and 2016FEBE053) and the Scientific and the Technical Research Council of Turkey (TUBITAK, 113Y568). 


\section{References}

[1] Henze J, Randall DG. “Microbial induced calcium carbonate precipitation at elevated $\mathrm{pH}$ values $(>11)$ using Sporosarcina pasteurii". Journal of Environmental Chemical Engineering, 6(4), 5008-5013, 2018.

[2] Canakci H, Sidik W, Kilic IH. "Effect of bacterial calcium carbonate precipitation on compressibility and shear strength of organic soil". Soils and Foundations, 55(5), 1211-1221, 2015.

[3] Bundur ZB, Amiri A, Ersan YC, Boon N, Belie ND. "Impact of air entraining admixtures on biogenic calcium carbonate precipitation and bacterial viability". Cement and Concrete Research, 98, 44-49, 2017.

[4] Ferris FG, Phoenix V, Fujita Y, Smith RW. "Kinetics of calcite precipitation induced by ureolytic bacteria at 10 to $20{ }^{\circ} \mathrm{C}$ in artificial groundwater". Geochimica et Cosmochimica Acta, 68 (8), 1701-1710, 2004.

[5] Chu J, Stabnikov V, Ivanov V. "Microbially induced calcium carbonate precipitation on surface or in the bulk of soil". Geomicrobiology Journal, 29 (6), 544-549, 2012.

[6] Amiri A, Azima M, Bundur ZB. "Crack remediation in mortar via biomineralization: Effects of chemical admixtures on biogenic calcium carbonate". Construction and Building Materials, 190, 317-325, 2018.

[7] Ksara M, Newkirk R, Langroodi SK, Althoey F, Sales , Schauer CL, Farnam Y. "Microbial damage mitigation strategy in cementitious materials exposed to calcium chloride". Construction and Building Materials, 195, 1-9, 2019.

[8] Qabany A, Soga K, Santamarina C. "Factors affecting efficiency of microbially induced calcite precipitation". Journal of Geotechnical and Geoenvironmental Engineering, 138 (8), 992-1001, 2012.

[9] Li Q, Zhang B, Ge Q, Yang X. "Calcium carbonate precipitation induced by calcifying bacteria in culture experiments: Influence of the medium on morphology and mineralogy". International Biodeterioration \& Biodegradation, 134, 83-92, 2018.

[10] Zhu T, Lin Y, Lub X, Dittrich M. "Assessment of cyanobacterial species for carbonate precipitation on mortar surface under different conditions". Ecological Engineering, 120, 154-163, 2018.

[11] Schwantes-Cezario N, Medeiros LP, De Oliveira Jr. AG, Nakazato G, Kobayashi RKT, Toralles BM. "Bioprecipitation of calcium carbonate induced by Bacillus subtilis isolated in Brazil". International Biodeterioration and Biodegradation, 123, 200-205, 2017.

[12] Zhuang D, Yan H, Tucker ME, Zhao H, Han Z, Zhao Y, Sun B, Li D, Pan J, Zhao Y, Meng R, Shan G, Zhang X, Tang R. "Calcite precipitation induced by Bacillus cereus MRR2 cultured at different $\mathrm{Ca}^{2+}$ concentrations: Further insights into biotic and abiotic calcite". Chemical Geology, 500, 64-87, 2018.

[13] Bang SS, Galimat JK, Ramakrishan V. "Calcite precipitation induced by polyurethane-immobilized Bacillus pasteurii". Enzyme and Microbial Technology, 28(4-5), 404-409, 2001.

[14] Rodriguez-Navarro C, Rodriguez-Gallego M, Chekroun KB, Muñoz MT. "Conservation of ornamental stone by Myxococcus xanthus-induced carbonate biomineralization". Applied and Environmental Microbiology, 69(4), 2182-2193, 2003.
[15] Lee NY. "Calcite production by Bacillus amyloliquefaciens CMB01". Journal of Microbiology, 41(4), 345-348, 2003.

[16] Chahal N, Rajor A, Siddique R. "Calcium carbonate precipitation by different bacterial strains". African Journal of Biotechnology, 10(2), 8359-8372, 2011.

[17] Akyol E, Bozkaya 0, Dogan NM. "Strengthening sandy soils by microbial methods". Arabian Journal of Geosciences, 10(327), 1-8, 2017.

[18] American Public Health Association (APHA). "Standard methods for the Examination of Water and Wastewater". Washington, USA, $17^{\text {th }}$ ed.,1989.

[19] Weatherburn MW. "Phenol-hypochlorite reaction for determination of ammonia". Analytical Chemistry, 39(8), 971-974, 1967.

[20] Armstrong JM, Myers DV, Verpoorte JA, Edsall JT "Purification and properties of human erythrocyte carbonic anhydrases". Journal of Biological Chemistry, 241(21), 5137-5149, 1966.

[21] Sun X, Miao L, Tong T, Wang C. "Study of the effect of temperature on microbially induced carbonate precipitation". Acta Geotechnica, 14(3), 627-638, 2019.

[22] Omoregie AI, Ong DEL, Nissom PM. "Assessing ureolytic bacteria with calcifying abilities isolated from limestone caves for biocalcification". Letters in Applied Microbiology, 68 (2), 173-181, 2018.

[23] Mitchell AC, Ferris FG. "The Ca precipitation into calcite precipitates induced by bacterial ureolysis in artificial ground water: temperature and kinetics dependence". Geochimica Cosmochimica Acta, 69, 4199-4210, 2005.

[24] Rodriguez-Navarro C, Jimenez-Lopez C, RodriguezNavarro A, Gonzalez-Munöz MT, Rodriguez-Gallego M. "Bacterially mediated mineralization of vaterite". Geochimica Cosmochimica Acta, 71 (5), 1197-1213, 2007.

[25] Stocks-Fischer S, Galinate JK, Bang SS. "Microbiological precipitation of $\mathrm{CaCO}_{3}$ ". Soil Biology and Biochemistry, 31 (11), 1563-1571, 1999.

[26] Anne S, Rozen Bamu O, Andreazza P, Rouet JL. "Evidence of a bacterial carbonate coating on plaster samples subjected to the calcite bioconcept biomineralization techniques". Construction and Building Materials, 24 (6), 1036-1042, 2010.

[27] Prah J, Mǎcek J, Drǎzic G. "Precipitation of calcium carbonate from a calcium acetate and ammonium carbamate batch system". Journal of Crystal Growth, 324 (1), 229-234, 2011.

[28] Hammes F, Boon N, de Villiers J, Verstraete W, Siciliano SD. "Strain-Specific ureolytic microbial calcium carbonate precipitation". Applied and Environmental Microbiology, 69(8), 4901-4909, 2003.

[29] Li W, Chen WS, Zhou PP, Cao L, Yu LJ. "Influence of initial $\mathrm{pH}$ on the precipitation and crystal morphology of calcium carbonate induced by microbial carbonic anhydrase". Colloids and Surfaces B: Biointerfaces, 102, 281-287, 2013.

[30] Chunxiang Q, Jianyun W, Ruixing W, Liang C. "Corrosion protection of cement-based building materials by surface deposition of $\mathrm{CaCO}_{3}$ by Bacillus pasteurii". Materials Science and Engineering C, 29(4), 1273-1280, 2009.

[31] Obst M, Dynes JJ, Lawrence JR, Swerhone GDW, Benzerara K., Karunakaran C, Kaznatcheev K, Tyliszczak T, Hitchcock AP. "Precipitation of amorphous $\mathrm{CaCO}_{3}$ (aragonite-like) by cyanobacteria: A STXM study of the influence of EPS on the nucleation process". Geochimica et Cosmochimica Acta, 73 (14), 4180-4198, 2009. 
[32] Kaur DN, Reddy SM, Mukherjee A. "Biomineralization of calcium carbonate polymorphs by the bacterial strains isolated from calcareous sites". Journal of Microbiology and Biotechnology, 23(5), 707-714, 2013.

[33] Priya JN, Kannan M. "Effect of carbonic anhydrase and urease on bacterial calcium carbonate precipitation". Int. Journal of Pharma and Bio Science, 8(3), 609-614, 2017.
[34] Sensoy T, Bozbeyoglu NN, Dogan NM, Bozkaya O, Akyol E. "Characterization of Calcium Carbonate Produced by ureolytic bacteria (Sporocarcina pasteurii ATCC 6453 and Bacillus aerius U2) and Effect of Environmental Conditions on Production of Calcium Carbonate". https://cest.gnest.org/sites/default/files/presentation_fi le_list/cest2017_00840_poster_paper.pdf. (19.04. 2017). 